JOURNAL OF AGRICULTURE AND APPLIED BIOLOGY

2020, Vol. 1, No. 2, $38-45$

http://dx.doi.org/10.11594/jaab.01.02.01

Research Article

\title{
Growth and yield of maize (Zea mays L.) as influenced by date of sowing and hybrids
}

\author{
Dadapeer Belaghatta Hasan Sab*, Shankarapp Sridhara, Pradeep Gopakkali \\ Center for Climate Resilient Agriculture, University of Agricultural and Horticultural Sciences, \\ Shivamonggo 577204, India
}

Article history:

Submission 14 September 2020

Accepted 5 October 2020

Published 21 December 2020

Keywords:

Dry matter production

Kernel yield

LAI

Hybrids

*Corresponding author:

E-mail:

sridharas1968@gmail.com

\begin{abstract}
A field experiment was conducted at college of Agriculture, UAHS, Shivamogga during kharif 2015 to study the effect of date of sowing and hybrids on growth and yield of Maize (Zea mays L.). The experiment was laid out in randomized complete block design (RCBD) with factorial concept and replicated thrice. There were eight treatment combinations which includes four dates of sowing $\left(15^{\text {th }}\right.$ June, $30^{\text {th }}$ June, $15^{\text {th }}$ July and $30^{\text {th }}$ July) and two hybrids (PAC-740 and CP-818). Crop sown on $15^{\text {th }}$ June recorded significantly higher plant height $(201.03 \mathrm{~cm})$, number of green leaves (3.03), leaf area $\left(992.49 \mathrm{~cm}^{2}\right)$, LAI (0.74), total dry matter (305.65 g), cob length $(22.16 \mathrm{~cm})$, kernels $\mathrm{cob}^{-1}$ (670.93), kernel yield $\mathrm{cob}^{-1}$ (230.95 g), test weight (43.08 g), kernel yield (7632.57 $\mathrm{kg} \mathrm{ha}^{-1}$ ), stover yield (9512.56 kg ha-1) and harvest index (44.52\%) as compared to other sowing dates. Among the hybrids CP -818 recorded significantly higher plant height (191.85 $\mathrm{cm})$, number of green leaves (2.72), leaf area $\left(954.32 \mathrm{~cm}^{2}\right)$, LAI (0.71), total dry matter (277.65 g), cob length $(19.81 \mathrm{~cm})$, kernels cob-1 (541.88), kernel yield cob-1 $^{-1} 207.71 \mathrm{~g}$ ), test weight (39.16 g), kernel yield (7060.72 $\left.\mathrm{kg} \mathrm{ha}^{-1}\right)$, Stover yield (8839.98 $\left.\mathrm{kg} \mathrm{ha}^{-1}\right)$ and harvest index (44.44\%) as compared to PAC-740. The interaction between dates of sowing and hybrids are non-significant.
\end{abstract}

\section{Introduction}

Maize is the third most important cereal crop in India because of its fast growing nature, ease of cultivation, high yielding potential, easy to process, readily digestible and higher profitability. Rainfed farming is the backbone of Indian agriculture, as large areas of cultivated land is rainfed. The success or failure of rainfed crops depends mostly on the pattern of monsoon rains and its distribution. Apart from rainfall thermal environment experienced by the crop also decides the maize productivity (Mehdi, 2012). Key planting factors influencing maize production are sowing date and cultivars. Different genotypes may behave differently under similar environmental conditions. Different sowing dates might create different environmental conditions from emergence to physiological maturity (Mehdi, 2012). The variation in planting dates modifies the microclimate to which the plants are exposed and it is responsible for biomass production and ultimately the yield. It is necessary to understand the knowledge of plant environment interaction for increasing yield of crop. Maize yields

\section{How to cite:}

Sab, D. B. H., Sridhara, S., \& Gopakkali, P. (2020). Growth and yield of maize (Zea mays L.) as influenced by date of sowing and hybrids. Journal of Agriculture and Applied Biology, 1 (2), 38 - 45. doi: 10.11594/jaab.01.02.01 
are higher when sown with the onset of monsoon. However, during recent years after the onset of monsoon, rains are delayed with dry spells leading to delayed sowing resulted in poor growth and yield. Maize is predominantly grown under rainfed condition in Southern Transition Zone of Karnataka. The occurrence of mid-season or late season drought is very common resulting in lower productivity of maize. This calls for identification of suitable hybrids of contrasting duration as well as sowing dates to realise higher yield of maize. With this background a field experiment was conducted to identify the suitable sowing date and hybrid for Southern Transition Zone of Karnataka.

\section{Materials and Methods}

A field experiment was conducted at College of Agriculture, University of Agricultural and Horticultural Sciences, Shivamogga, Karnataka during kharif 2015. Which is situated at $14^{\circ} 0^{1}$ to $14^{0} 1^{1}$ North latitude and $75^{0} 40^{1}$ to $75^{0}$ $42^{1}$ East longitude with an altitude of 650 meters above mean sea level. The climate is hot, moist, sub-humid, and the annual rainfall ranges from $820 \mathrm{~mm}$ to $910 \mathrm{~mm}$. More than 60 percent is received in the Kharif season, which is normal rainfall of $550 \mathrm{~mm}, 166 \mathrm{~mm}$ in the pre-monsoon and $207 \mathrm{~mm}$ in the northeast monsoon rainfall. The soil of the experimental site was red sandy loam with $\mathrm{pH}$ 6.4, medium in soil organic carbon (0.55\%), low available $\mathrm{N}$ (232 kg ha-1), high available $\mathrm{P}_{2} \mathrm{O}_{5}\left(77.4 \mathrm{~kg} \mathrm{ha}^{-1}\right)$ and low in soil available $\mathrm{K}_{2} \mathrm{O}\left(193.5 \mathrm{~kg} \mathrm{ha}^{-1}\right)$. Eight treatment combinations which includes four dates of sowing (15 th June, 30 thJune,

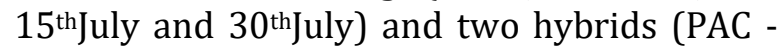
740 and $C P$ - 818) were tried in a randomized complete block design with factorial concept and replicated thrice. The recommended dose of manure (10 t FYM ha-1) was applied 15 days before sowing and incorporated into the soil. Recommended dose of fertilizer (150:75:40 kg NPK ha-1) for each treatment was appliedin terms of urea, SSP and MOP fertilizers. Furrows were opened at $45 \mathrm{~cm}$ interval with the help of hand hoe. Basal dose of fertilizers $(50 \% \mathrm{~N}$ and $100 \% \mathrm{P}$ and $\mathrm{K}$ ) were applied at the time of sowing and remaining $50 \%$ of $\mathrm{N}$ was applied in two splits at 30 and 60 days after sowing.
The pre-emergent herbicide (Atrazine) was sprayed on the day of sowing to all the plots at the rate of $1.5 \mathrm{~kg}$ a. i. ha- ${ }^{-1}$. The plots were weeded manually twice at 30 and 50 days after sowing. Growth parameters like plant height, number of leaves, leaf area, and total dry weight were recorded at 30, 60, 75, 90, 105 DAS and at harvest. Yield parameters like cob length, cob girth, kernels per cob, kernel yield per cob and test weight were recorded at harvest. The data was subjected to statistical analysis by using SPSS software V20. Further, date of sowing was converted in to into Julian day on which a particular treatment was sown and grain yield was regressed against Julian days sowing to assess the effect of sowing dates on yield of maize.

\section{Results and Discussion}

The growth parameters of maize as influenced by date of sowing and hybrids at harvest were presented in table 1 . Crop sown on $15^{\text {th }}$ June recorded significantly higher plant height $(201.03 \mathrm{~cm})$, number of green leaves (3.03), leaf area (992.49 $\left.\mathrm{cm}^{2}\right)$, LAI (0.74) and total dry matter (305.65 g) as compared to other sowing dates. Among the hybrids CP -818 recorded significantly higher plant height $(191.85 \mathrm{~cm})$, number of leaves (2.72), leaf area $\left(954.32 \mathrm{~cm}^{2}\right)$, LAI (0.71) and total dry matter accumulation (277.65 g) as compared to PAC 740. Interaction between date of sowing and hybrids did not influence the growth parameters significantly. The optimum planting time play an important role in deciding the productivity and reducing climate risk especially in rainfed areas. Availability of adequate soil moisture in different crop growth and development stages is a deciding factor for its yield and yield attributes. Crop sown on $15^{\text {th }}$ June has received adequate rainfall $(738.4 \mathrm{~mm})$ and the mean temperature ranges from 24.5 to $26.6^{\circ} \mathrm{C}$ during different growth stages viz., emergence to knee high stage, knee high stage to tasseling, tasseling to silking and silking to maturity (Fig. 1). Whereas, rainfall of 553.6, 598.6, 520.8mm and mean temperature ranges from 24.4 to $26.6^{\circ} \mathrm{C}$, 24.8 to $24.3^{\circ} \mathrm{C}$ and 26.0 to $24.9^{\circ} \mathrm{C}$ for July $1^{\text {st }}$, July $15^{\text {th }}$ and July $30^{\text {th }}$ Sown crop respectively. Both rainfall and temperature play key role in production of dry matter and accumulation of 
higher leaf area and leaf area index. Similar findings were reported by Keerthi, et al. (2017); Umesh et al. (2017); Chavan and Chavan (2010) and Marjan et al. (2010) in maize. Significantly higher value of growth parameters recorded with $\mathrm{CP}-818$ might be due to maximum utilization of solar energy and soil moisture for longer period due to its long duration in nature. Higher LAI due to higher leaf area and leaf number per plant resulted higher dry matter accumulation.

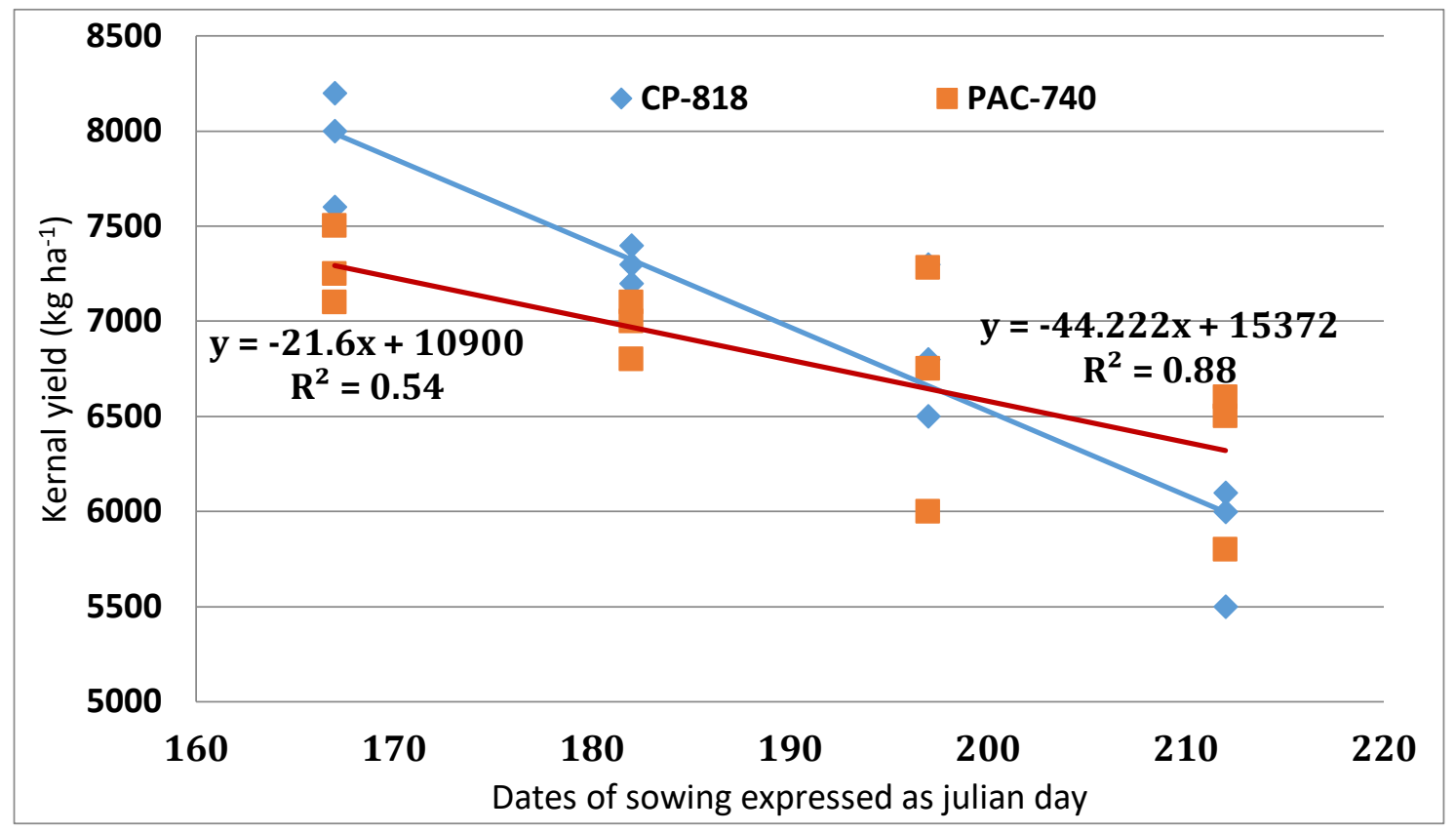

Figure 1. Relationship between kernel yield of maize hybrids and dates of sowing expressed as Julian day

It was revealed that maize cultivars had differential response to sowing date in yield attributes such as cob length $(22.16 \mathrm{~cm})$, kernels $\mathrm{cob}^{-1}$ (670.93), kernel yield $\mathrm{cob}^{-1}$ (230.95 g), test weight $(43.08 \mathrm{~g})$, kernel yield $(7632.57 \mathrm{~kg}$ ha $\left.^{-1}\right)$, stover yield ( $\left.9512.56 \mathrm{~kg} \mathrm{ha}^{-1}\right)$ and harvest index (44.52\%) were found significantly higher in $15^{\text {th }}$ June sowing. It could be due to the better growth and development of crop as Kolawole and Samson (2009), Nielson (2002) reported that due to the fact that good photosynthates accumulated in leaves and its transfer to economic part like grains and cobs. This research showed that early sowing produced greater yields compared to late sowing and also the lowest yield was obtained for the late sowing (Table 2). In addition, the late sowing date has a higher probability of experiencing water stress during the critical seed-filling phase, resulting in lower yields (Sandeep et al., 2014). It might be suggested in this study that the late planted crop had a shorter period for the production of seed and a slightly lower rate of seed production due to reduced growth, and exposure of plants to warmer and longer photoperiod (long day) after the late sowing date. Similar findings were also reported by Rowland et al. (2013) and Angel (2019). These differences were also largely related to the number of developing seed on cob. The per cent yield reduction under delayed sowing are June $30^{\text {th }}(5.59$ $\%)$, July $15^{\text {th }}(11.65 \%)$ and July $30^{\text {th }}(20.16 \%)$. 
DBH Sab, S Sridhara, P Gopakkali, 2020 / Growth and yield of maize (Zea mays L.) as influenced by date of sowing and hybrids

Table 1. Growth parameters of maize as influenced by date of sowing and hybrids

\begin{tabular}{lccccc}
\hline Treatments & $\begin{array}{c}\text { Plant height } \\
(\mathrm{cm})\end{array}$ & $\begin{array}{c}\text { Number of } \\
\text { Leaves }\end{array}$ & $\begin{array}{c}\text { Leaf area } \\
\left(\mathrm{cm}^{2}\right)\end{array}$ & $\begin{array}{c}\text { Leaf area } \\
\text { index (LAI) }\end{array}$ & $\begin{array}{c}\text { Total dry } \\
\text { weight (g) }\end{array}$ \\
\hline Dates of sowing (D) & & & & & \\
\hline Jun-15 & 201.03 & 3.03 & 992.49 & 0.74 & 305.65 \\
Jun-30 & 188.36 & 2.83 & 962.83 & 0.71 & 277.00 \\
Jul-15 & 184.30 & 2.50 & 926.25 & 0.69 & 257.57 \\
Jul-30 & 180.56 & 2.37 & 905.49 & 0.67 & 247.93 \\
\hline F - test & $*$ & $*$ & $*$ & $*$ & $*$ \\
\hline S. Em \pm & 0.96 & 0.07 & 7.10 & 0.005 & 2.85 \\
C.D. at 5\% & 2.96 & 0.21 & 21.52 & 0.02 & 8.66 \\
\hline Hybrids (H) & & & & & \\
\hline PAC - 740 & 185.78 & 2.65 & 939.29 & 0.70 & 266.43 \\
CP - 818 & 191.85 & 2.72 & 954.32 & 0.71 & 277.65 \\
F - test & $*$ & NS & $*$ & NS & $*$ \\
S. Em \pm & 0.68 & 0.05 & 5.02 & 0.004 & 2.02 \\
C.D. at 5\% & 2.09 & - & - & - & 6.12 \\
\hline Interaction (H X D) & & & & & \\
\hline PAC - 740 + June 15 & 194.40 & 3.00 & 980.34 & 0.73 & 295.30 \\
PAC - 740 + June 30 & 186.26 & 2.73 & 960.70 & 0.71 & 272.37 \\
PAC -740 + July 15 & 183.26 & 2.47 & 917.64 & 0.68 & 255.60 \\
PAC -740 + July 30 & 179.20 & 2.40 & 898.49 & 0.67 & 242.43 \\
CP - 818 + June 15 & 206.66 & 3.07 & 1004.64 & 0.74 & 316.00 \\
CP - 818 + June 30 & 190.46 & 2.93 & 964.98 & 0.71 & 281.63 \\
CP - 818 + July 15 & 185.33 & 2.53 & 935.18 & 0.69 & 259.53 \\
CP - 818 + July 30 & 181.93 & 2.33 & 912.49 & 0.68 & 253.43 \\
F - test & NS & NS & NS & NS & NS \\
S. Em \pm & 1.37 & 0.10 & 10.03 & 0.007 & 4.04 \\
C.D. at 5\% & -- & - & - & - & - \\
\hline & & & & & \\
\hline & & & & & \\
\hline
\end{tabular}


Table 2. Yield and yield parameters of maize as influenced by date of sowing and hybrids

\begin{tabular}{|c|c|c|c|c|c|c|c|}
\hline Treatments & $\begin{array}{l}\text { Cob length } \\
(\mathrm{cm})\end{array}$ & Kernels /cob & $\begin{array}{l}\text { Kernel yield } \\
\left(\mathrm{g} \mathrm{cob}^{-1}\right)\end{array}$ & $\begin{array}{l}\text { Test weight } \\
\text { (g) }\end{array}$ & $\begin{array}{l}\text { Kernel yield } \\
\left(\mathrm{kg} \mathrm{ha}^{-1}\right)\end{array}$ & $\begin{array}{l}\text { Stover yield } \\
\left(\mathrm{kg} \mathrm{ha}^{-1}\right)\end{array}$ & $\begin{array}{c}\text { Harvest index } \\
(\%)\end{array}$ \\
\hline \multicolumn{8}{|c|}{ Dates of sowing (D) } \\
\hline Jun-15 & 22.16 & 670.93 & 230.95 & 43.08 & 7632.57 & 9512.56 & 44.52 \\
\hline Jun-30 & 20.30 & 533.86 & 208.30 & 38.81 & 7205.77 & 9132.53 & 44.11 \\
\hline Jul-15 & 18.36 & 472.66 & 194.21 & 36.27 & 6743.32 & 8485.98 & 44.28 \\
\hline Jul-30 & 17.43 & 416.76 & 171.23 & 32.96 & 6093.63 & 7760.25 & 44.03 \\
\hline F - test & * & $*$ & * & $*$ & $*$ & $*$ & NS \\
\hline S. Em \pm & 0.21 & 9.45 & 5.90 & 1.01 & 129.78 & 86.95 & 0.34 \\
\hline C.D. at $5 \%$ & 0.65 & 28.96 & 18.08 & 3.09 & 393.64 & 263.75 & - \\
\hline \multicolumn{8}{|l|}{ Hybrids (H) } \\
\hline PAC - 740 & 19.31 & 505.23 & 194.64 & 36.40 & 6776.93 & 8605.68 & 44.03 \\
\hline CP - 818 & 19.81 & 541.88 & 207.71 & 39.16 & 7060.72 & 8839.98 & 44.44 \\
\hline F - test & * & $*$ & * & $*$ & $*$ & $*$ & NS \\
\hline S. Em \pm & 0.15 & 6.68 & 4.17 & 0.71 & 91.77 & 61.49 & 0.32 \\
\hline C.D. at 5\% & 0.46 & 20.47 & 12.78 & 2.19 & 278.35 & 186.50 & - \\
\hline
\end{tabular}


DBH Sab, S Sridhara, P Gopakkali, 2020 / Growth and yield of maize (Zea mays L.) as influenced by date of sowing and hybrids

\begin{tabular}{|c|c|c|c|c|c|c|c|}
\hline \multicolumn{8}{|l|}{ Interaction (H X D) } \\
\hline PAC - $740+$ June 15 & 21.73 & 630.00 & 219.50 & 41.30 & 7282.13 & 9041.30 & 44.61 \\
\hline PAC - $740+$ June 30 & 20.20 & 515.86 & 199.13 & 37.38 & 6947.83 & 8755.00 & 44.25 \\
\hline PAC -740 + July 15 & 17.93 & 457.46 & 190.92 & 36.04 & 6594.00 & 8329.27 & 44.19 \\
\hline PAC -740 + July 30 & 17.40 & 417.60 & 169.00 & 30.88 & 6283.73 & 8297.17 & 43.10 \\
\hline CP - 818 + June 15 & 22.60 & 711.86 & 242.39 & 44.87 & 7983.00 & 9983.83 & 44.43 \\
\hline CP - 818 + June 30 & 20.40 & 551.86 & 217.48 & 40.24 & 7463.70 & 9510.07 & 43.97 \\
\hline CP - 818 + July 15 & 18.80 & 487.86 & 197.50 & 36.49 & 6892.63 & 8642.70 & 44.37 \\
\hline CP - 818 + July 30 & 17.46 & 415.93 & 173.46 & 35.04 & 5903.53 & 7223.33 & 44.97 \\
\hline F - test & NS & NS & NS & NS & NS & NS & NS \\
\hline S. Em \pm & 0.30 & 13.37 & 8.35 & 1.43 & 183.53 & 122.97 & 0.65 \\
\hline C.D. at $5 \%$ & - & - & - & & - & - & - \\
\hline
\end{tabular}


Significantly higher yield and yield parameters like cob length $(19.81 \mathrm{~cm})$, kernels cob $^{-1}$ (541.88), kernel yield cob-1 $^{-1}$ (207.71 g), test weight (39.16 g), kernel yield (7060.72 kg ha${ }^{1}$ ), stover yield (8839.98 $\mathrm{kg} \mathrm{ha}^{-1}$ ) and harvest index $(44.44 \%)$ were recorded with CP-818 as compared to PAC-740 (Table 2). Higher growth and yield parameters were mainly due to higher values of growth attributes in CP-818 at all stages of crop growth coupled with its higher photosynthetic efficiency due to its optimum LAI and canopy spread which might have led to stimulation of longer sink in terms of longer cobs. Khan et al. (2002), Golla et al. (2019), Dahmardeh (2012) and Maga (2015) also reported differential response of maize varieties when exposed to different environmental conditions by means of sowing at different dates. It is also well-known fact that number of kernels per cob were higher in longer cobs than small ones apart from this the better cob filling resulted in higher kernel yield. The interaction effect is non-significant. However, the crop sown on $15^{\text {th }}$ June along with CP - 818 hybrid recorded higher yield as compared to other dates of sowing. Similarly, crop sown on $30^{\text {th }}$ July along with CP-818 hybrid resulted lower yield.

\section{Conclusion}

The result shows that maize crop sown on $15^{\text {th }}$ June was significantly better as compared to other sowing dates for the studied parameters of growth and yield. Similarly, CP-818 hybrid is well suited for early sowing for southern transitional zone of Karnataka.

\section{Conflict of Interest}

There is no conflict of interest

\section{Authors Contribution}

DBH (Post Graduate Student): Conducted field experiments and recorded field observations. SS (Professor of Agronomy): Conceived the idea and supervised the experiment and written the concept and discussion. PG (Technical Officer): written the draft, data analysis and references.

\section{References}

Angel M., Astrid B., Francisca S., \& Jaume L. (2019). Sowing date affects maize development and yield in irrigated mediterranean environments. Agriculture, 9(3), 67. https://www.mdpi.com/2077$\underline{0472 / 9 / 3 / 67}$

Chavan P. G., \& Chavan S.A. (2010). Effect of sowing dates and plant spacing on growth, yield and yield attributes of rabi sweet corn under lateritic soils of Konkan. Journal of Indian Society of Coastal Agricultural. Research, 28(1), 55-57. https://www.greenfarming.in/?articles=effect-of-sowing-dates-and-plantspacing-on-growth-yield-yield-attributes-of-rabisweet-corn-under-lateritic-soils-of-konkan

Dahmardeh, M. (2012). Effects of sowing date on the growth and yield of maize cultivars (Zea mays L.) and the growth temperature requirements. African Journal of Biotechnology, 11, 12450-12453.

https://doi.org/10.5897/AJB12.201

Golla, B., Tadesse, B., Chalsisa, D., \& Bayisa, E. (2018). Effect of sowing time and environmental variation on yield of different Maize varieties. Open Journal of Plant Science, 3(1), 041-045. http://dx.doi.org/10.17352/ojps.000014

Keerthi P., Prabhakara R.G., \& SunithaN. (2017). Effect of sowing time on growth and yield of sweet corn cultivars. International. Journal of Current Microbiology \& Applied Sciences, 6(4), 777-782.

https://www.ijcmas.com/6-42017/P.\%20Keerthi,\%20et\%20al.pdf

Khan, N., Qasim, M., Ahmed, F., Naz, F., Khan, R., Khanzada, S. A., \& Khan, B. A. (2002). Effect of sowing dates on yield of maize under agro-climatic condition of Kaghan valley. Asian Journal of Plant Science, 1(2), 146-147. https://doi.org/10.3923/ajps.2002.146.147

Kolawole, E., \& Samson, U. (2009). Growth and yield of maize as influenced by sowing date and poultry manure application. Notulae Botanicae Horti Agrobotanici Cluj-Napoca,37,199-203.

https://www.notulaebotanicae.ro/index.php/nbha/article/view/3140

Liaqat, W., M. Akmal \& J. Ali. 2018. Sowing date effect on production of high yielding maize varieties. Sarhad Journal of Agriculture,34(1), 102-113. http://dx.doi.org/10.17582/journal.sja/2018/34.1.102.113 
Maga, T. J., Vange, T., \& Ogwuche, J. O. (2015). The influence of sowing dates on the growth and yield of two maize (Zea mays L.) varieties cultivated under Southern Guinea Savannah Agro-Ecological Zone. American Journal of Experimental Agriculture, 5(3), 200-208.

https://doi.org/10.9734/AJEA/2015/12661.

Marjan P., Rahim N., \& Reza S. (2010). Efficiency of some sweet corn hybrids at two sowing dates in central Iran. Middle-East. Journal of Scientific Research, 6(1), 51-55.

http://www.idosi.org/mejsr/mejsr6(1)10/9.pdf.

Mehdi, D. (2012). Effects of sowing date on the growth and yield of maize cultivars (Zea mays L.) and the growth temperature requirements. African Journal of Biotechnology, 11(61), 12450-12453.

Nielson, R. L., Thomison, P. R., Brown, G. A., Halter, A. L., Wells, J., \& Wuethricc., K. L. (2002). Delayed planting date effects on flowering and grain maturation of corn. Agronomy Journal, 94, 549- 558.

https://doi.org/10.2134/agronj2002.0549

Rowland T.S., Gregory O.E, James P.M., \& Peter D.K.

(2013). The effect of planting date on maize grain yields and yield components. Field Crops Research, 150, 135-144.

https://doi.org/10.1016/i.fcr.2013.05.028

Sandeep, V., Kanaka, D. P., \& Neelima. (2014). Effect of sowing date on maize seed yield and quality: A review. Review of Plant Studies, 1(2), 26-38.

http://www.conscientiabeam.com/pdffiles/agr/69/RPS-2014-1(2)-26-38.pdf

Umesh, S., Lal, P. A., Tika, B. K., Khem, R. D., \& Jiban, S. (2017). Effect of sowing dates and maize cultivars in growth and yield of maize along with their agroclimatic indices in Nawalparasi, Nepal. Journal of AgriSearch, 3(1), 57-62. https://jsure.org.in/journal/index.php/jas/article/view/226 